\title{
A Case Study of Thinking out of the Box in Electrical Engineering
}

\author{
Lia Elena Aciu ${ }^{1}$, Petre Lucian Ogrutan ${ }^{2}$ \\ ${ }^{1}$ Transilvania University of Brasov, Department of electrical engineering and applyied physics, \\ 9 Eroilor Bvd, Brasov, Romania \\ ${ }^{2}$ Transilvania University of Brasov, Department of electronics and computers, \\ 9 Eroilor Bvd, Brasov, Romania
}

\begin{abstract}
The current context of rapid evolution of IT technologies and devices (Information Technology) imposes changes in engineering education. Education for the development of creativity becomes a requirement. This paper presents a new concept for the development of creativity by introducing an optional homework for Applied Electronics students, the final year of undergraduate studies. The homework requires electronic design of an application in the field of art of each student's diploma project. The paper presents the results of this initiative and the analysis of students' feedback. A statistical pilot study was organized that highlighted students' opinions about creativity as well as students' reasons for doing or not doing the optional homework.
\end{abstract}

Keywords - Engineering education, Creativity, Art, Lateral thinking.

\section{Introduction}

Creativity has a major contribution to the development of current technology. The 21 st century is marked by an unprecedented technological evolution and university education has to keep up with this evolution "While it is true that

DOI: $10.18421 /$ TEM103-32

https://doi.org/10.18421/TEM103-32

Corresponding author: Lia Elena Aciu, Transilvania University of Brașov, Electrical engineering and applied physics Dpt.

Email: lia aciu@unitbv.ro

Received: 30 Jun 2021.

Revised: 19 July 2021.

Accepted: 29 July 2021.

Published: 27 August 2021.

(c) BY-Nc-ND (C) 2021 Lia Elena Aciu \& Petre Lucian Ogrutan; published by UIKTEN. This work is licensed under the Creative Commons AttributionNonCommercial-NoDerivs 4.0 License.

The article is published with Open Access at www.temjournal.com certain basics of engineering will not change, there will be an increased premium for some skills (such as lifelong learning, meta-learning, collaboration, creativity, critical thinking, communication skills, and cultural/global literacy)" [1].

Creativity is considered a way to achieve a higher standard of living and engineering education has to develop creativity. An analysis of the definitions of creativity is presented in [2]. This paper classifies and compares the definitions of creativity in dictionaries, starting with the 1950s, and the diversity of these definitions is noted. The best known definition is given by Runco and Jaeger [3], a definition explained and elaborated in several papers. According to the initial definition "Creativity requires both originality and effectiveness". In [4] the authors examine in detail the term "effectiveness" in the definition, which applies perfectly if creativity brings financial benefits but is difficult to generalize. The authors quote clarification proposals for "effectiveness" using "adaptation to reality", "valuable" or "acceptable".

The development of creativity can be trained through Lateral thinking or Thinking out of box. The notion of Thinking out of box was introduced by Edward de Bono [5]. The connection with creativity is given in the statement "Lateral thinking is closely related to creativity". Nevertheless, whereas creativity is too often only the description of a result, lateral thinking is the description of a process, Bono's definition states "It is as definite a way of using the mind as logical thinking but a very different way." The concept is nuanced in [6] "Lateral thinking involves deliberate mental efforts to change more automatic or habitual responses that have been shaped through perceptual frameworks." A paper in the field of philosophy [7] analyzes the connection between creativity and Lateral thinking. In connection with creativity but also with understanding reality, it is necessary to develop Critical Thinking in students. In [8] are presented the results obtained by students in the critical analysis of some texts. The results are worrying, "many students 
do not possess basic thinking skills" and "many students lack the ability to keep separate their own views, the author's views, and the external data."

In this context, at the Faculty of Electrical Engineering and Computer Science in Brașov, Romania, methods have been constantly sought to develop students' creativity. One of the reference works addressing this subject with a focus on the difficulties of moving from imitation to creativity is [9].

In order to develop the creativity of Applied Electronics students and to train them the way of Thinking out of box, it was proposed to create homework in which they had to design an application of each diploma project in the field of art.

There is a wide variety of diploma project fields, software, hardware, image processing, embedded devices, etc. Thus it is not easy for engineering students to imagine an application of their project in the field of art, a field about which they know very little. Such an application can only be imagined by using Thinking out of box and Critical Thinking and only after searching for information in the field of art. In order to stimulate the students to do this project, a bonus of maximum one point was provided in the evaluation at the end of the semester. In order to analyze the effectiveness of this initiative, a pilot study was conducted in which students completed a questionnaire and had the opportunity to communicate their personal opinions.

\section{The Connection Between the Fields of Art and Engineering}

The technological progress of the last years has determined the spread in the field of art of computerbased systems and peripheral equipment. Suffice it to mention is the smartphone and 3D printers. A paper that justifies the interdependence between art and the use of technology [10] shows in an example that there can no longer be music without the help of electronic devices, but also mentions that excessive use of technology can affect the essence of art. Current achievements adopted in museums and virtual exhibitions accelerated by the Sars-Cov2 pandemic make full use of technology, based on high-performance computing systems and advanced algorithms. In [11] the authors present some best practices in the field of virtual reality applied to visits in museums and virtual exhibitions. An original achievement is described in [12], the transformation of a poem into visual images by $3 \mathrm{D}$ printing of various shapes inspired by the sounds generated when reciting the poem.

In terms of art education, the book [13] examines the challenges that have arisen today. A chapter is dedicated to one of the challenges, digitization and computer-based technologies. Paper [14] presents the results of a study that analyzes the attitude of 305 students who are preparing to become teachers in art education. The study shows a favorable attitude towards the digital skills needed by art students. The paper [15] analyzes the possibility of integrating art in STEM education (Science, Technology, Engineering, and Mathematics) "to improve creativity, critical thinking, reasoning skills, aesthetic sensibilities and appreciation." The multidisciplinary nature of STEM by introducing the study of art can provide the necessary qualities for 21 st century researchers. The authors' initiative was applied to three courses by introducing small projects, laboratory works and multidisciplinary simulations [15].

Artists with advanced digital skills use the opensource Processing library and Integrated Development Environment (IDE) to support the creation of works of art [16]. The authors present the bidirectional relationship between artists and computer specialists. Thus, it is proposed that for Computer Science students, in addition to programming, the introduction of an Animation and Multimedia course for the development of artistic skills [17]. Paper [18] analyzes the digital knowledge of art students and finds worrying shortcomings.

The students from Applied Electronics at the Faculty of Electrical Engineering and Computer Science, Transilvania University of Brasov had little to do with art. Some of them took part time jobs during their studies in areas related to art, others had various passions. Thus, some of the diploma projects aimed at creating devices or software programs related to art.

One of the projects consisted of a system of mirrors using a laser beam for writing texts on a fog screen at concerts; another project was an image of a piano keyboard projected on the floor that could be played while stepping on the keys. Most of the projects were in the field of music, for example the actuation of a motorized drum that controls the timing and the force of the strike (Figure 1).

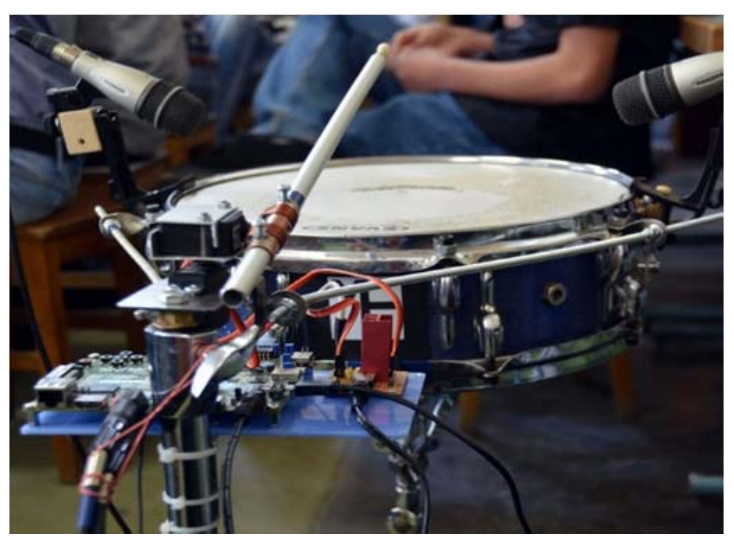

Figure 1. Drum strike actuation 
Another project presents a harp with virtual strings consisting of LED-phototransistor pairs (Figure 2), then an electronic music synthesizer. In the field of image analysis, a project was developed to restore old paintings in Romania, affected in the course of time.

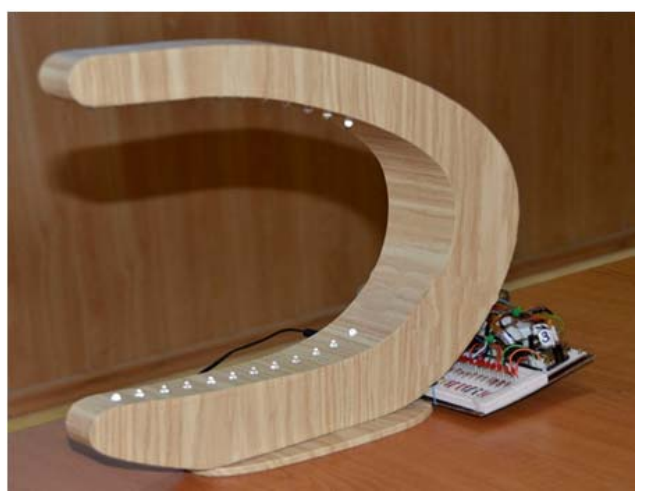

Figure 2. Virtual string harp

\section{Educational Research}

In the academic year 2020-2021, an experiment was proposed that aimed to identify students' opinions about thinking processes and their ability to use engineering knowledge in a different field, such as art. The experiment was conducted with a group of students from Applied Electronics in Interfacing and Peripheral Equipment. The students were assigned in the 2nd semester of the 4th study year (duration 10 weeks) an optional homework in which to develop, at a theoretical level, an application of their diploma project in the field of art. The homework was not simple, the students had to study various fields of art and identify in which field and how their project can be applied. The most interesting achievements of the students with the homework "My diploma project and art" were:

1. A diploma project on the subject of indoor environment monitoring (temperature, humidity, flammable gases, etc.) has been adapted for the monitoring of a museum room;

2. A project that performs lighting control to ensure constant illumination regardless of ambient light has been adapted to provide the illumination of a painting.

3. Object recognition using artificial intelligence algorithms has been adapted for the recognition of works of art in order to analyze the flow of visitors in museums;

4. A machine learning application that runs on the mobile phone, able to recognize paintings, to provide user information about the author and the temporal context of the historical period in which a painting was achieved;

5. A very uncommon way to combine art and engineering was illustrated by the project of a student who found no better connection with art than to paint the project wiring diagram on Easter eggs using old Romanian traditional methods.

To obtain a small-scale preliminary result of the effectiveness of introducing such an optional homework in all specializations, a pilot study was conducted with a group of students from Applied Electronics. A questionnaire (Table 1) was designed that included 30 items measured on a five point Likert scale, with 15 questions for those who did the homework and 15 for those who did not. The study was attended by 39 students, of which 14 students completed the questionnaire. The homework was completed by 12 students. The questions were similar to those in [9].

Table 1. Questionnaire for the students who complete the project

\begin{tabular}{|c|c|c|c|c|}
\hline & $\begin{array}{l}\text { Questionnaire for the students } \\
\text { who complete the project }\end{array}$ & $\mathbf{A}$ & $\mathbf{M}$ & SD \\
\hline 1. & $\begin{array}{l}\text { I set out to do the homework the } \\
\text { moment I was aware of its } \\
\text { existence. }\end{array}$ & 3.80 & 4.00 & 1.50 \\
\hline 2. & $\begin{array}{l}\text { I think the homework was } \\
\text { helpful in developing creativity }\end{array}$ & $4.00 *$ & 4.00 & 1.09 \\
\hline 3. & $\begin{array}{l}\text { I think that the lack of time was } \\
\text { a factor that affected the quality } \\
\text { of solving the homework }\end{array}$ & 3.40 & 4.00 & 1.37 \\
\hline 4. & $\begin{array}{l}\text { I think that what I learned } \\
\text { during the } 4 \text { years of study } \\
\text { helped me to do the homework }\end{array}$ & 3.00 & 3.00 & 1.09 \\
\hline 5. & $\begin{array}{l}\text { After completing the } \\
\text { homework, I consider that it } \\
\text { was very complex and difficult }\end{array}$ & $1.80 *$ & 1.50 & 0.81 \\
\hline 6. & $\begin{array}{l}\text { I think the extra bonus point for } \\
\text { the homework was important. }\end{array}$ & 3.40 & 4.00 & 1.50 \\
\hline 7. & $\begin{array}{l}\text { I would have chosen to do the } \\
\text { homework even if it had not } \\
\text { been rewarded. }\end{array}$ & 3.20 & 3.50 & 1.47 \\
\hline 8. & $\begin{array}{l}\text { I think the homework was } \\
\text { related to the need for creativity } \\
\text { on the labor market. }\end{array}$ & $4.00 *$ & 5.00 & 1.60 \\
\hline 9. & $\begin{array}{l}\text { I was able to better understand } \\
\text { creativity after doing the } \\
\text { homework. }\end{array}$ & 3.00 & 3.00 & 1.26 \\
\hline 10. & $\begin{array}{l}\text { I think I will use the way of } \\
\text { thinking that I have learned on } \\
\text { doing this homework in the } \\
\text { future }\end{array}$ & 3.20 & 3.50 & 1.36 \\
\hline 11. & $\begin{array}{l}\text { I think solving the homework } \\
\text { was too much of a waste of } \\
\text { resources }\end{array}$ & $1.40^{*}$ & 1.00 & 0.51 \\
\hline 12. & $\begin{array}{l}\text { I think I learned new things } \\
\text { from solving this homework }\end{array}$ & 3.60 & 3.50 & 0.81 \\
\hline 13. & $\begin{array}{l}\text { The time allotted for solving the } \\
\text { homework was justified by the } \\
\text { bonus point received }\end{array}$ & $4.60 *$ & 5.00 & 0.51 \\
\hline 14. & $\begin{array}{l}\text { The issue of the connection } \\
\text { between electronics and art is } \\
\text { worth raising }\end{array}$ & 3.60 & 4.00 & 1.50 \\
\hline 15. & $\begin{array}{l}\text { I enjoyed solving the homework } \\
\text { because I managed to complete } \\
\text { it }\end{array}$ & $4.80^{*}$ & 5.00 & 0.40 \\
\hline
\end{tabular}


The questionnaire was completed by 14 students, of which 6 did the homework and 8 did not. Each question was scored in Table 1 Average (A), Median (M) and Standard Deviation (SD). The answers were marked using an asterisk $\left(^{*}\right)$ with value A greater than or equal to 4 and those with value A less than or equal to 2, which will be discussed. To these questions the students had answers that show a high degree of similar opinions.

Table 2. Questionnaire for the students who did not complete the project

\begin{tabular}{|c|c|c|c|c|}
\hline & $\begin{array}{l}\text { Questionnaire for the } \\
\text { students who did not } \\
\text { complete the project }\end{array}$ & A & M & SD \\
\hline 16. & $\begin{array}{l}\text { Lack of time prevented me } \\
\text { from solving the homework. }\end{array}$ & $4.50^{*}$ & 5.00 & 1.06 \\
\hline 17. & $\begin{array}{l}\text { I consider that I did not have } \\
\text { the necessary knowledge to } \\
\text { solve the homework }\end{array}$ & $1.88^{*}$ & 2.00 & 0.83 \\
\hline 18. & $\begin{array}{l}\text { I don't think the extra bonus } \\
\text { point for the homework was } \\
\text { important }\end{array}$ & 2.38 & 2.00 & 1.59 \\
\hline 19. & $\begin{array}{l}\text { I think that the development of } \\
\text { creativity has nothing to do } \\
\text { with what is really happening } \\
\text { in the labor market. }\end{array}$ & $1.88^{*}$ & 2.00 & 0.83 \\
\hline 20. & $\begin{array}{l}\text { I think I can understand } \\
\text { creativity and I'm creative even } \\
\text { if I haven't solved the } \\
\text { homework. }\end{array}$ & $4.50^{*}$ & 5.00 & 0.75 \\
\hline 21. & $\begin{array}{l}\text { I think that solving the } \\
\text { homework would have meant } \\
\text { too much waste of resources } \\
\text { apart from time }\end{array}$ & 2.13 & 2.00 & 0.83 \\
\hline 22. & $\begin{array}{l}\text { I was not informed of the } \\
\text { possibility of doing the } \\
\text { homework }\end{array}$ & $1.50^{*}$ & 1.00 & 1.06 \\
\hline 23. & $\begin{array}{l}\text { The extra bonus point that is } \\
\text { added to the grade is too small }\end{array}$ & $1.63 *$ & 1.50 & 0.74 \\
\hline 24. & $\begin{array}{l}\text { I'm not interested in art } \\
\text { applications }\end{array}$ & 2.38 & 2.00 & 0.91 \\
\hline 25. & $\begin{array}{l}\text { I don't need bonus points } \\
\text { because I don't study for grades }\end{array}$ & 3.63 & 3.50 & 1.06 \\
\hline 26. & $\begin{array}{l}\text { I didn't do the homework } \\
\text { because I don't see its } \\
\text { usefulness in developing } \\
\text { creativity }\end{array}$ & 1.63 & 1.00 & 1.06 \\
\hline 27. & $\begin{array}{l}\text { I didn't do the homework } \\
\text { because it was too complex }\end{array}$ & 2.75 & 2.50 & 1.48 \\
\hline 28. & $\begin{array}{l}\text { Solving the homework would } \\
\text { have required learning too } \\
\text { many new things in the field of } \\
\text { art }\end{array}$ & 3.13 & 3.00 & 1.45 \\
\hline 29. & $\begin{array}{l}\text { Solving the homework would } \\
\text { have required learning too } \\
\text { much software }\end{array}$ & 2.13 & 2.00 & 1.24 \\
\hline 30. & $\begin{array}{l}\text { Solving the homework would } \\
\text { have entailed learning too } \\
\text { much hardware }\end{array}$ & 2.38 & 2.00 & 1.40 \\
\hline
\end{tabular}

The students who did the homework consider that it contributed to the development of creativity (question $2, \mathrm{~A}=4.00$ ) and that the homework was related to the need for creativity in the labor market (question $8, \mathrm{~A}=4.00$ ), while students who did not solve it consider that they can be creative even if they have not solved the homework (question 20, $\mathrm{A}=$ 4.50). The students who did the homework considered that the completion of the project brought them satisfaction (question $15, \mathrm{~A}=4.80$ ), did not mean too much consumption of resources (question 11, $\mathrm{A}=1.40$ ) and the time needed to solve the homework was compensated by the bonus point received (question 13, $\mathrm{A}=4.60$ ). Students who did not solve the homework consider (Table 2) the lack of time (question $16, \mathrm{~A}=4.50$ ) as a cause, and do not consider as causes the lack of knowledge (question $17, \mathrm{~A}=1.88)$, the fact that they were not informed (question 22, $\mathrm{A}=1.50$ ), or that the bonus is too small (question 23, $\mathrm{A}=1.63$ ). Also, the students who did not do the homework, as well as those who did, consider that the development of creativity is related to the labor market (question 19, $\mathrm{A}=1.88$ ).

A more detailed analysis of the students' answers was made considering the main objectives pursued with this homework and presented in the paper, i.e. the students' opinions about creativity and the reasons invoked by those who did not do the homework.

The answers of the students who did the homework to questions 2, Table 1 (I think the homework was useful to develop creativity) and 8 (I think the homework was related to the need for creativity in the labor market are represented in Figure 3).

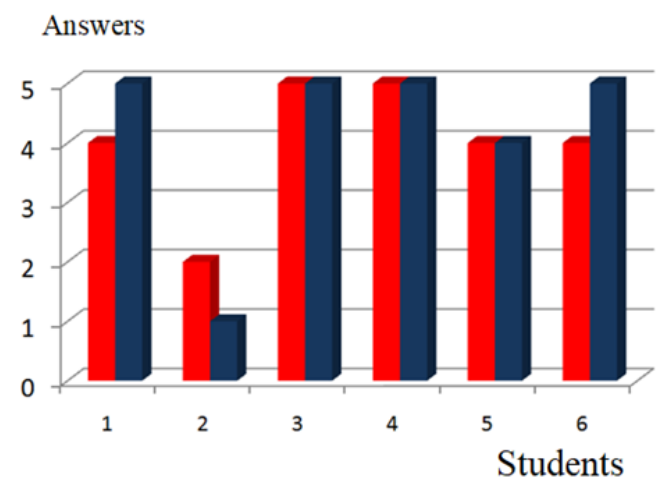

Figure 3. Answers of the students who did the homework to questions 2 (in red) and 8 (in blue)

Five out of six students who did the homework and completed the questionnaire consider the homework to be useful and very useful for the development of creativity (average 4) and for the necessary preparation for the labor market (average 4). One student finds them of very little use. This last opinion could be explained due to the student's contact with jobs which use employees as simple executants. 
The answers of the students who did not do the homework to questions 19 (I think that the development of creativity has nothing to do with what is really happening in the labor market) and 26 (I did not do the homework because I do not see its usefulness in developing creativity) are represented in Figure 4. In order to be able to compare with the answers in Figure 3 the scores were reversed because questions 19 and 26 contain a negation.

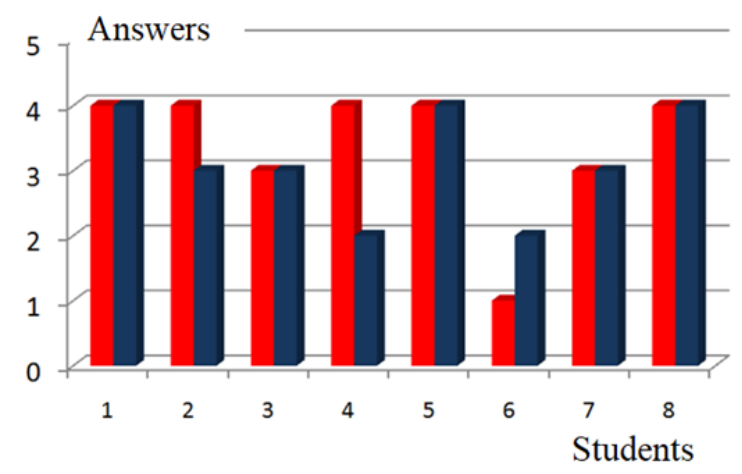

Figure 4. Answers of the students who did not do the homework to questions 19 (in blue) and 26 (in red)

All students who didn't do the homework as well as those who did with one exception consider that it is important for the development of creativity (average 3.37). The connection of creativity with the labor market is considered less important in contrast with the opinion of the students who did the homework (average 3.12). In conclusion, even if they did not do the homework, there is unanimous recognition of the importance of creativity.

The main causes invoked by the students who did not do the homework as they result from the questionnaires are given in Figure 5.

Answers

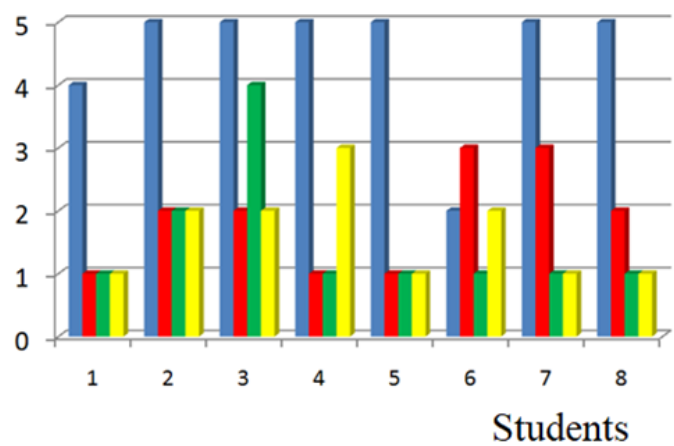

Figure 5. The main causes invoked by students who did not do the homework

The answers to question 16 (Lack of time prevented me from solving the homework) are marked in blue and also the main cause is considered. In red are the answers to question 17 (I consider that I did not have the necessary knowledge to solve the homework), in green are the answers to question 22 (I was not informed of the possibility of doing the homework), in which only one student largely considers that he was not informed. The answers to question 23 are marked in yellow (the bonus added to the grade is too small). The main cause identified in the questionnaires is lack of time (average 4.5), the next cause is lack of knowledge (average 1.88), then too little bonus (average 1.63) and then lack of information (average 1.5). Study [9] also indicates lack of time as a cause for not solving the homework. With regard to these causes one can envisage attempts to help students to allocate more time by managing and standardizing tasks during the study period before the final year.

A selection of some of the opinions of the students who did the homework is given below: "If this homework did not exist, I would not have discovered so many important aspects and the connection between electronics and art"; "The homework created a different perspective for me as a student and I enjoyed the research work for this homework"; "I learned that in any field we can discover close and pleasant connections with art and the environment"; "Electrical engineering, as well as other branches of engineering has a close connection with art"; "I enjoyed the challenge to think differently. I think the bonus was welcome and this homework did not require much effort. I enjoyed discovering a new way of thinking and applicability in art of a theoretical, technological work"; "If two fields differ it does not mean that a connection cannot be made between them"; "Thinking creatively is beneficial in any field"; "Art and engineering are not as different as I thought at first."

An analysis of the quality level of solving the homework (average grades 8.16) compared to the average grades obtained by the student group in Interfacing and Peripheral Equipment (7.26) shows that not only the best students did the homework. The correlation between the students' grades for the homework and the previously mentioned course was also analyzed and a weak positive correlation resulted (Pearson correlation of +0.23 ).

An analysis of the situation of students (with or without a job) shows that out of the total number of respondents 8 have a job and 6 do not have a job, and of those who did the homework 4 have a job and 2 do not, which shows that there is no significant connection between solving the homework and the fact that students have a job, which affects their time spent on education.

\section{Conclusions}

The experiment of encouraging "Thinking out of box" by creating a homework that would make a connection between the diploma project and the field of art produced interesting results. Only 12 students did this homework, i.e. $30.77 \%$, a lower percentage than expected, when considering the extra point granted at the assessment. The questionnaire 
designed to identify students' motivation was completed by 14 students that is $35.89 \%$. The opinions of the students who did the homework were positive, they appreciated the importance of Thinking out of box and the knowledge about art acquired. The students who did the homework consider that it had a major contribution to the development of creativity (average 4.00) and that the homework was related to the need for creativity in the labor market (average 4.00). The bonus point awarded was considered important but to some extent (average 3.20), the students would have done the homework even if there was no bonus.

The most important cause invoked by the students who did not do the homework was lack of time, which is credible. The solutions found by the students for the homework had a high degree of originality. As the diploma projects had different topics, collaboration between students to find common solutions was impossible. The average degree of similarities reported by Turnitin for the homework was 4.66 , and the work with the highest degree of similarities had $16 \%$. The values of similarities were below those expected for a work that contained part of a description of a field of art.

The data obtained through this pilot study have a limited degree of relevance because the sample of students surveyed was small. However, the results of the study encourage the extension of the initiative to a larger number of students. Generalizing the completion of a homework that involves Thinking out of box would be welcomed in the current context of technological developments and employer requirements. The authors of this initiative do not expect visible results from a large number of students; rather they hope to provide a useful training for some students. Through discussions between teachers and students, other homework can be imagined to develop students' creativity. The idea of homework for students to establish a connection with the field of art emerged from the passion of some students for art, which materialized in the achievement of outstanding diploma projects.

\section{References}

[1]. Qadir, J., Yau, K. L. A., Imran, M. A., \& Al-Fuqaha, A. (2020, October). Engineering Education, Moving into 2020s: Essential Competencies for Effective 21st Century Electrical \& Computer Engineers. In 2020 IEEE Frontiers in Education Conference (FIE) (pp. 19). IEEE.

[2]. Hennessy, J. L., \& Patterson, D. A. (2011). Computer architecture: a quantitative approach. Elsevier.

[3]. Robinson, J. R. (2008). Webster's dictionary definition of creativity. Online Journal for Workforce Education and Development, 3(2), 2.
[4]. Runco , M. A. ( 1988 ). Creativity research: Originality, utility, and integration. Creativity Research Journal, 1(1), 1-7.

[5]. Runco, M. A., \& Jaeger, G. J. (2012). The standard definition of creativity. Creativity research journal, 24(1), 92-96.

[6]. De Bono, E., \& Zimbalist, E. (1970). Lateral thinking (pp. 1-32). London: Penguin.

[7]. Dingli, S. (2008). Thinking outside the box: Edward de Bono's lateral thinking. In The Routledge companion to creativity (pp. 352-364). Routledge.

[8]. Alexopoulos, K., \& Scaltsas, T. (2018, June). Creativity through Lateral Thinking Techniques. In Proceedings of the XXIII World Congress of Philosophy (Vol. 68, pp. 11-17).

[9]. Kuhn, D. (2005). Education for thinking. Harvard University Press.

[10]. Ogrutan, P., Cazan, A. M., \& Aciu, L. E. (2017). Difficulties of evolution from imitation to creativity in engineering education. The International journal of engineering education, 33(6), 1815-1823.

[11]. Shen, Y. (2020, October). Analysis of the Possibility of Art Theory Construction from the Perspective of Art Image based on Computer-aided Analysis. In Journal of Physics: Conference Series (Vol. 1648, No. 3, p. 032146). IOP Publishing.

[12]. Kang, Y., \& Yang, K. C. (2020). Employing digital reality technologies in art exhibitions and museums: A global survey of best practices and implications. In Virtual and augmented reality in education, art, and museums (pp. 139-161). IGI Global.

[13]. Budescu, A., Chirilă, D. D., Gui, O., Dascălu, C., Uszkai, M., \& Simu, M. (2019). Poetry Based 3D Printed Sculpture. Proceedings of EVA London 2019, 376-380.

[14]. Davies, T., \& Worrall, P. (2003). Thinking out of the box: Developments in specialist art and design teacher education and ICT. In Issues in art and design teaching (pp. 106-113). Routledge.

[15]. Kara, S. (2020). Prospective Visual Arts Teachers' Innovation Skills and Attitudes towards Computer Assisted Instruction. International Journal of Technology in Education and Science, 4(2), 98-107.

[16]. Zaher, A. A., \& Hussain, G. A. (2020, April). STEAM-based Active Learning Approach to Selected Topics in Electrical/Computer Engineering. In 2020 IEEE Global Engineering Education Conference (EDUCON) (pp. 1752-1757). IEEE.

[17]. Woolley, S., \& Collins, T. (2021, March). Art for Computer Scientists: Processing as an open-source art medium for computer science undergraduates. BCS.

[18]. Budescu, A., Drăgan-Chirilă, D., \& Gui, O. (2018). Inserting new concepts into a traditional arts school: The University of Art and Design Cluj-Napoca, Romania. Politics of the Machines-Art and After 7, $1-4$. 